\title{
Antiphospholipid Antibody Measurement
}

National Cancer Institute

\section{Source}

National Cancer Institute. Antiphospholipid Antibody Measurement. NCI Thesaurus. Code C102258.

The determination of the amount of antiphospholipid antibodies present in a sample. 